\title{
The use of sunn hemp as green manure intercropped with taro
}

\author{
Fábio Luíz de Oliveira'; José Guilherme M Guerra²; Raul de LD Ribeiro ${ }^{3}$; Dejair Lopes de Almeida²; \\ Edmilson Evangelista da Silva ${ }^{4}$ Segundo Urquiaga ${ }^{2}$; José Antônio A Espindola ${ }^{2}$ \\ ${ }^{1}$ UFVJM, FCA, Dep ${ }^{\text {to }}$ de Agronomia, Rua da Glória, n. 187, 39100-000 Diamantina-MG; '2Embrapa Agrobiologia, C. postal 74505,

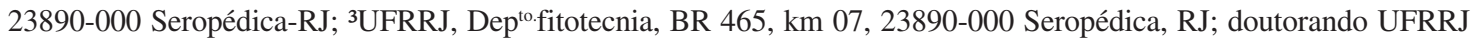 \\ fabio@ufvjm.edu.br; edmilson@cnpab.embrapa.br
}

\begin{abstract}
An experiment was carried out in Magé, Rio de Janeiro State, Brazil, to evaluate the performance of taro (Colocasia esculenta) intercropped with sunn hemp (Crotalaria juncea), used as green manure. A randomized blocks design with four replicates was used and the soil of the field plots was classified as Haplic Gleysol. Treatments consisted of taro (1) intercropped with unpruned sunn hemp, (2) intercropped with sunn hemp cut at soil level, (3) intercropped with sunn hemp pruned at its mid-height, and (4) in monoculture. The taro was planted in double rows spaced by $1.0 \mathrm{~m}$. The planting furrows had a space of $0.5 \mathrm{~m}$, with rhizomes placed at every $3.0 \mathrm{~m}$. The experimental plot consisted of four $3.0 \mathrm{~m}$ rows and the useful area corresponded to the five central plants in each of the two central rows. The sunn hemp was sown in parallel lines in the spaces between the taro double rows, 120 days after planting the taro. When the sunn hemp was cut at soil level, an accumulation of $211 \mathrm{~kg} \mathrm{ha}^{-1}$ of $\mathrm{N}$ was observed. Besides this, the sunn hemp's biomass promoted the cycling of an average $17 \mathrm{~kg} \mathrm{ha}^{-1}$ of $\mathrm{P}, 85 \mathrm{~kg} \mathrm{ha}^{-1}$ of $\mathrm{K}$, $151 \mathrm{~kg} \mathrm{ha}^{-1}$ of $\mathrm{Ca}$, and $27 \mathrm{~kg} \mathrm{ha}^{-1}$ of $\mathrm{Mg}$. Worth mentioning, it represented also a deposition of $6.85 \mathrm{Mg} \mathrm{ha}^{-1}$ of dry substance. Even when pruned at its mid-height, the sunn hemp still provided $60 \%$ of nutrients relatively to the treatment in which it was cut at soil level. In addition to the nutrient supply, the use of taro intercropped with sunn hemp cut at soil level or pruned at mid-height represented efficient alternatives for controlling the spontaneous vegetation and for reducing taro leaf burning by solar radiation, without compromising the yield of taro. In all intercropping systems, taro plants had a larger leaf area and were taller than plants in monoculture.
\end{abstract}

Keywords: Crotalaria juncea, Colocasia esculenta, organic farming, leaf area, leaf burning, weed control.

\section{RESUMO}

Utilização de crotalária como adubo-verde em consórcio com taro

O experimento foi desenvolvido no município de Magé, Região Metropolitana do estado do Rio de Janeiro, para avaliar a influência do manejo da crotalária (Crotalaria juncea), usada como adubo verde, na forma de consórcio, sobre o desempenho do taro. O solo da área experimental foi classificado como Gleissolo Háplico. O delineamento experimental foi blocos casualizados com quatro repetições. Os tratamentos consistiram de cultivo do taro (1) consorciado com crotalária sem cortes, (2) consorciado com crotalária roçada rente ao nível do solo, (3) consorciado com crotalária cortada à metade de sua altura e (4) em monocultivo. O taro foi plantado em fileiras duplas espaçadas de $1,0 \mathrm{~m}$. Os sulcos de plantio tiveram espaçamento de $0,5 \mathrm{~m}$, com os rizomas colocados a cada $3,0 \mathrm{~m}$. A parcela experimental consistiu de quatro linhas de $3,0 \mathrm{~m}$, adotando como área útil as cinco plantas centrais em cada uma das linhas do meio. A crotalária foi semeada em linhas paralelas, no espaço entre os sulcos, 120 dias após o plantio do taro. Quando a crotalaria foi cortada rente ao solo, houve um acúmulo de $211 \mathrm{~kg} \mathrm{ha}^{-1}$ de $\mathrm{N}$, além da reciclagem de, em média, $17 \mathrm{~kg} \mathrm{ha}^{-1}$ de $\mathrm{P}, 85 \mathrm{~kg} \mathrm{ha}^{-1} \mathrm{de} \mathrm{K}, 151 \mathrm{~kg}$ $\mathrm{ha}^{-1}$ de Ca e $27 \mathrm{~kg} \mathrm{ha}^{-1}$ de $\mathrm{Mg}$. Observou-se ainda a deposição de $6,85 \mathrm{Mg} \mathrm{ha}^{-1}$ de matéria seca. Mesmo quando cortada a meia altura, a crotalária ainda forneceu $60 \%$ de nutrientes em relação ao tratamento em que foi cortada rente ao solo. Além do fornecimento de nutrientes, a utilização do taro consorciado com crotalária, quando esta foi roçada ao nível do solo ou cortada à metade de sua altura, foi eficaz para controle da vegetação espontânea e para redução da incidência de queimaduras foliares causadas pela radiação solar, sem comprometer o rendimento do taro. Independente do manejo da crotalária, as plantas de taro apresentaram maior área foliar e foram mais altas quando cultivadas em consórcio do que em monocultivo.

Palavras-chave: Crotalaria juncea, Colocasia esculenta, agricultura orgânica, área foliar, queimaduras foliares, controle do mato.

(Recebido para publicação em 7 de março de 2006; aceito em 28 de setembro de 2007)

$\mathrm{M}$ onocultures can cause undesirable consequences to agriculture and to the environment. Gliessman (2005) emphasized that the choice for monoculture in a determined area can create problems proceeding from the increase of the susceptibility to pests, biodiversity reduction, and a less efficient use of the available natural resources, such as water, light, and nutrients. Among the alternative practices to reach a broader diversity in the agroecosystem, we highlight green manure. The use of leguminous plants as green manure, besides the Nitrogen provision which comes from the process of biologic fixation for cultures of economic interest, limits the erosion risks and lessens the competition impact with spontaneous plants (Espindola et al.,2005).

Although green manure brings several advantages for the production systems, many farmers have been reluctant in adopting it as a precultivation method. The use of the land to produce green manure requires the maintenance of agriculture fields without an economic return in the short run, which makes it unviable, mainly for family farmers. This way, the use of green manure intercropped with vegetables may be more interesting (Moreira, 2003) For instance, Ribas et al. (2003) found that okra intercropped with sunn hemp (Crotalaria juncea) 
showed higher productivity than okra in monoculture, in spite of the high incidence of root galls due to the presence of nematodes of the Meloidogyne genus.

Taro (Colocasia esculenta) is a plant of considerable nutritional value and high level of starch, which makes it useful for both using it as food in natura, as well as a product in the agroindustry (Vilpoux, 2001). Among the factors that limit its yield, particularly in organic systems, we may cite the competition with spontaneous plants and the leaf burning, caused by the direct incidence of solar rays (Oliveira et al, 2004). The cultivation of taro intercropped with green manure could contribute to the overcoming of such problems and consequently to improve yield.

This study aimed at the evaluation of the management of the sunn hemp used as green manure, in intercropping systems, on taro performance in the edaphoclimatic conditions of Magé, Rio de Janeiro State.

\section{MATERIAL AND METHODS}

The experiment was installed in a commercial production area of taro in Magé, 2002. The area is located at $10 \mathrm{~m}$ above sea level, in a warm region (annual average of $26^{\circ} \mathrm{C}$ ), with annual pluvial average of $1033 \mathrm{~mm}$ and long periods of drought. The soil of the experimental area was classified as Haplic Gleysol, usually cultivated with vegetables. The chemical analyses of the soil, in the layer of 0-20 cm, presented: $\mathrm{pH}$ (in water $=5.9 ; \mathrm{Al}^{3+}=0.0 \mathrm{cmol} \mathrm{dm}_{\mathrm{c}} \mathrm{dm}^{-3}$; $\mathrm{Ca}^{2+}=5.5 \mathrm{cmol}_{\mathrm{c}} \mathrm{dm}^{-3} ; \mathrm{Mg}^{2+}=1.4 \mathrm{cmol}_{\mathrm{c}}$ $\mathrm{dm}^{-3} ; \mathrm{K}^{+}=265 \mathrm{mgkg}^{-1}$; and $\mathrm{P}=101 \mathrm{mg}$ $\mathrm{kg}^{-1}$. The chemical composition of the utilized poultry manure presented: $\mathrm{N}=$ 32.7, $\mathrm{P}=8.4, \mathrm{~K}=11.2, \mathrm{Ca}=35.0$, and $\mathrm{Mg}=7.6 \mathrm{~g} \mathrm{~kg}^{-1}$.

A randomized block design with four replications was used in the experiment. Treatments consisted of (1) taro in monoculture, (2) taro intercropped with unpruned sunn hemp, (3) taro intercropped with sunn hemp cut at soil level, and (4) taro intercropped with sunn hemp pruned at its midheight. Taro planting took place in May, characterizing a winter culture. The taro was planted in double rows spaced by $1.0 \mathrm{~m}$. The planting furrows had a space of $0.5 \mathrm{~m}$ with rhizomes placed at every $3.0 \mathrm{~m}$. The experimental plot consisted of four $3.0 \mathrm{~m}$-long rows. The useful area corresponded to the five central plants in each of the two central rows.

The sunn hemp was sown in parallel lines in the spaces between the taro double rows, 120 days after planting the taro. Sunn hemp cuttings were made 120 days after seeding, when plants were in average $1.80 \mathrm{~m}$ tall. The cut biomass was placed in the taro interlines and kept as soil cover. The biomass Nitrogen level was determined by the Bremner \& Mulvaney (1982) method, whereas P, $\mathrm{K}$, $\mathrm{Ca}$, and $\mathrm{Mg}$ were quantified using the nitricperchloric digestion (Bataglia et al., 1983). The $\mathrm{P}$ level was checked by colorimetry, by means of the formation of the blue color of the complex of molibdate-phosphate in the presence of ascorbic acid. K was obtained by atomic absorption spectrophotometry (EMBRAPA, 1997). $\mathrm{Ca}$ and $\mathrm{Mg}$ contents were also determined by atomic absorption spectophotometry, after the referred nitricperchloric digestion (Bataglia et al., 1983).

By the time of the sunn hemp cutting, an assessment of the nitrogen biologic fixation was made through the method of the natural isotopic abundance ${ }^{15} \mathrm{~N}$ (Shearer \& Kohl, 1986). As a reference the following species were used: hairy beggarticks (Bidens pilosa), goosegrass (Eleusine indica), and corn (Zeas mays). The volumetric humidity and the temperature of the soil of the experimental area were also determined after the sunn hemp cutting. In addition, monthly evaluations of spontaneous plants incidence were carried out by counting the number of individuals by species present in the useful area of each plot. The aerial biomass of the sampled plants was also assessed.

Regarding taro, plant height (from soil level to the petiole insertion of the highest leaf), number of leaves, and total leaf area per plant were evaluated. Leaf area was calculated by measuring the diagonals linking the petiole insertion point to the three vertexes of the limb, through a method preconized by Nolasco (1984). Taro harvest took place in April 2003, and tillers average mass, number of tillers per plant, and yield of tillers and central rhizomes were measured. Furthermore, the incidence of leaf burning, due to the direct solar radiation over taro leaves was analyzed through a diagrammatic scale adaptation named Michereff, previously utilized by Oliveira (2004).

Significant differences among the factors studied were determined by variance analysis, using the $\mathrm{F}$ test. For those sources of variance in which the F was significant, the Tukey test was applied at a $5 \%$ level of probability.

\section{RESULTS AND DISCUSSION}

The use of sunn hemp as green manure intercropped with taro allowed a considerable addition of Nitrogen to the system. When the sunn hemp was cut at soil level, an accumulation of 211 $\mathrm{kg} \mathrm{ha}^{-1}$ of $\mathrm{N}$ was observed in its aerial biomass, $40 \%$ of this value $(84 \mathrm{~kg}$ ) proceeding from biologic fixation. Besides this, the sunn hemp's biomass managed in this way promoted the cycling of an average $17 \mathrm{~kg} \mathrm{ha}^{-1}$ of $\mathrm{P}, 85$ $\mathrm{kg} \mathrm{ha}^{-1}$ of $\mathrm{K}, 151 \mathrm{~kg} \mathrm{ha}^{-1}$ of $\mathrm{Ca}$, and 27 $\mathrm{kg} \mathrm{ha}{ }^{-1}$ of $\mathrm{Mg}$. Worth mentioning, it represented a great addition of organic matter, with a deposition of $6.85 \mathrm{Mg} \mathrm{ha}^{-1}$ of dry substance. Even when pruned at its mid-height, the sum hemp still provided $60 \%$ of nutrients relatively to the treatment in which it was cut at soil level.

Regarding the physical characteristics of the soil, it was noticed, 150 days after planting the taro (30 days after the sunn hemp cutting) that the soil temperature was lower in the treatment in which taro was intercropped with the sunn hemp without pruning than in the other treatments (Figure 1). Furthermore, the volumetric humidity of the soil increased when the sunn hemp was kept without cuttings, which may represent a positive factor for the intercropped cultivation of sunn hemp and taro, if this is the sunn hemp management chosen. The described results go with those found by Perin (2001), who showed that areas covered 

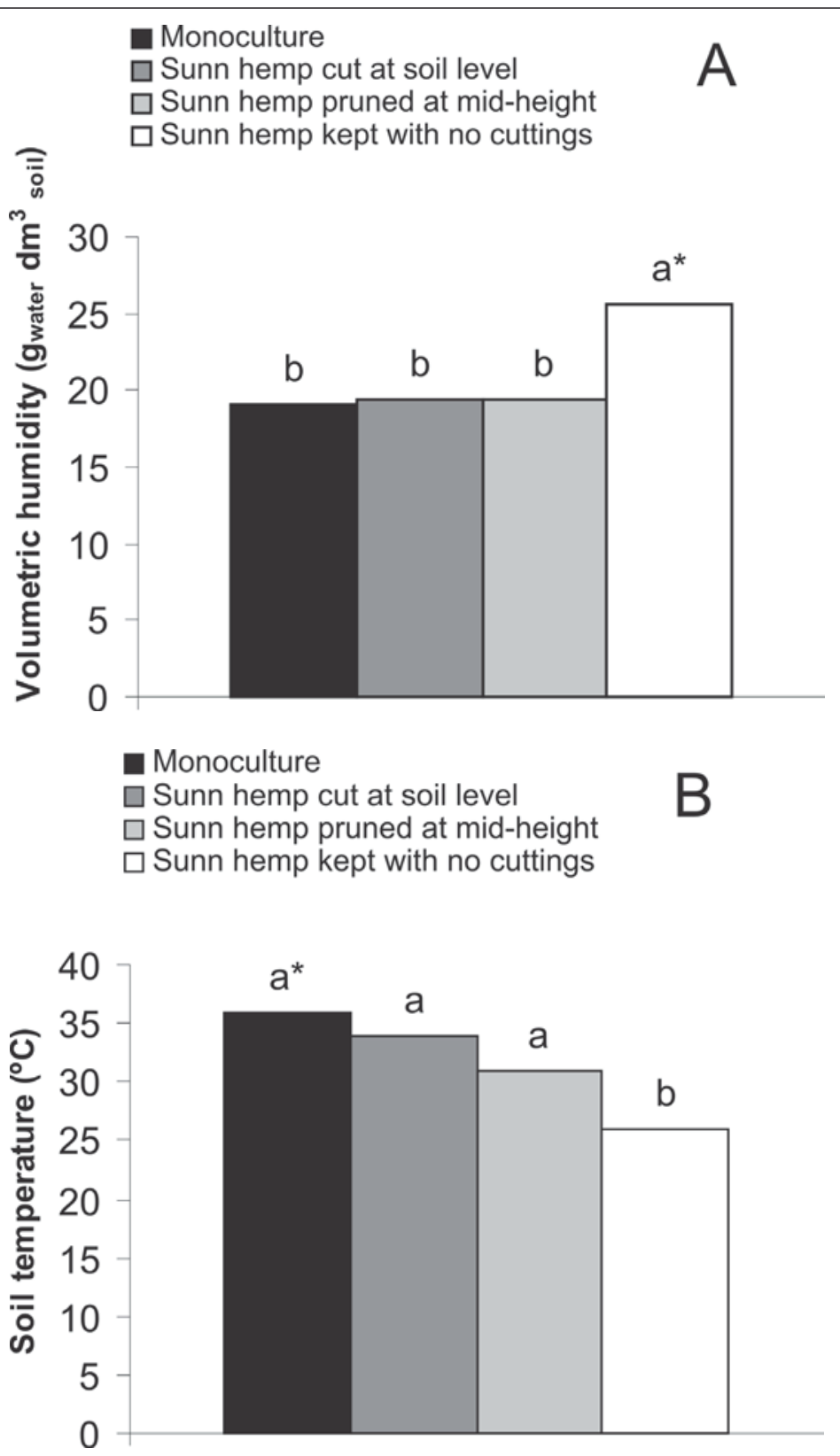

Figure 1. Volumetric humidity (A) and soil temperature (B), at the $0-20 \mathrm{~cm}$ layer, in taro monoculture and in intercropping with sunn hemp, 30 days after the sunn hemp management (umidade volumétrica e temperatura do solo, na camada de 0-20 cm, em monocultivo de taro e em consórcio com crotalária). Magé, UFRRJ, 2003.

Means followed by the same letter in the column do not differ from each other, Tukey's test, $\mathrm{p}<0.05$ (médias seguidas de mesma letra nas colunas não diferem entre si, teste de Tukey, $\mathrm{p}<0,05$ ).

with tropical kudzu (Pueraria phaseoloides) and siratro (Macroptilium atropurpureum) had higher humidity and lower soil temperature at the $0-5 \mathrm{~cm}$ layer than weeded areas.

The cultivation of taro intercropped with sunn hemp suppressed the spontaneous vegetation, as measured by the dry aerial biomass of the infesting species population (Table 1). In the treatment in which the sunn hemp was kept without cuttings, there was a more efficient covering of the soil, which might have lowered the acceleration of the spontaneous plants growth. Even when the sunn hemp was pruned, with its respective biomass left on the soil, there was a significant reduction of the spontaneous plants throughout the following month, comparatively to the plots with taro in monoculture. In the treatment in which the sunn hemp was pruned at mid-height, a suppressive effect over the spontaneous vegetation was detected until 60 days after cutting, in comparison to the monoculture, although with less intensity than when plants were pruned at the soil level. This might be due to the fact that the sunn hemp had already started regrowing at that time, which kept the level of competition with the spontaneous plants by water, light, and nutrients.

Fourteen species were identified forming the spontaneous vegetation of the experimental area, with a predominance of goosegrass (Eleusine indica), Bermuda grass (Cynodon dactylon), and hairy beggarticks (Bidens pilosa), which all together represented $90 \%$ of the collected samples. However, in the treatment in which the sunn hemp was kept unpruned the persistence or the reappearing of two species was identified: goosegrass and tropical spiderwort (Commelina benghalensis), the latter in lower frequency. When the sunn hemp was managed with cuttings, all the species turned up again, though in different frequencies in relation to the original.

It is known that the control of spontaneous plants increases production costs, mainly in long cycle cultures, such as taro (Pimenta, 1993). Once being an organic field, the control of spontaneous plants becomes more complex, considering that the use of herbicides is not tolerated. The use of sunn hemp in an intercropped system was as an adequate option to the organic taro production, making weeding unnecessary. Even in conventional cultivation, the intercropped system using taro and sunn hemp has the potential to replace at least partially the employment of herbicides.

The cultivation of taro intercropped with sunn hemp, by promoting the shading of the taro, significantly reduced the intensity of the leaf burning caused by solar radiation (Figure 2 ). The intercropped system with sunn hemp managed without cuttings was the most effective, eliminating such burning. When the sunn hemp was pruned at midheight, the leaf area damaged was three times smaller than what was observed in taro monoculture, until 30 days after 
the sunn hemp cutting. Within 60 days from the sunn hemp cutting, a smaller damaged area was still detected when compared to the monoculture. However, it is important to point out that by this time, the taro was about to complete its cycle, and such injury could even represent a benefit by accelerating the rhizome maturation.

Taro height and leaf area were also affected by the intercropped system with the sunn hemp. In all sunn hemp management in the intercropped system, taro plants expressed leaf area and height superior to the monoculture (Table 2). This behavior might be associated to the light income restriction, inducing a physiological plant response that resulted in leaf blade increase and petiole elongation. This was already expected for the plant need in sustaining the photosynthetic capacity in compensation to deficiencies in the wave length in the spectrum. Hence, one of the compensatory mechanisms would be to expand the photon absorption surface through the leaf blade expansion and the stimulus to the growth in height, in search of light capture (Taiz \& Zeiger, 1991). Leihner et al. (1996) observed identical phenomena in cassava plants raised between intercalated rows of Pigeon pea (Cajanus cajan) and leucaena (Leucaena leucocephala).

The intercropping with sunn hemp influenced the number of tillers per plant and tillers productivity, without altering, however, tiller average mass and central rhizome yield (Table 3). When intercropped with sunn hemp without cuttings, taro plants experienced a decrease in the number of tillers per plant and consequently a reduction in productivity. On the other hand, when the sunn hemp was pruned at soil level or pruned at mid-height, besides the benefits already shown in relation to the spontaneous vegetation control and protection against leaf burning, there was no reduction in the yield of tillers when compared to the monoculture.

General results allowed us to conclude that intercropping taro with sunn hemp cut at soil level or pruned at mid-height represent efficient alternatives for the spontaneous vegetation control and for the reduction of taro leaf burning by solar radiation. Such management of the sunn hemp in
Table 1. Aerial dry mass of the spontaneous vegetation in taro monoculture and intercropped with sunn hemp (massa seca da parte aérea de plantas espontâneas em monocultivo de taro e em consórcio com crotalária). Magé, UFRRJ, 2003.

\begin{tabular}{lcc}
\hline \multirow{2}{*}{ Cultivation system $^{1}$} & \multicolumn{2}{c}{ Dry mass (t ha-1 $^{-1}$} \\
\cline { 2 - 3 } & ${\mathbf{3 0 ~} \mathbf{D A M S H}^{\mathbf{2}}}^{\mathbf{6 0} \mathbf{D A M S H}^{\mathbf{2}}}$ \\
\hline Monoculture & $6,57 \mathrm{a}^{2}$ & $5,88 \mathrm{a}$ \\
Intercrop I & $1,03 \mathrm{~b}$ & $5,30 \mathrm{a}$ \\
Intercrop II & $1,48 \mathrm{~b}$ & $3,92 \mathrm{~b}$ \\
Intercrop III & $0,29 \mathrm{c}$ & $0,90 \mathrm{C}$ \\
\hline CV (\%) & 24,5 & 21,2 \\
\hline
\end{tabular}

Means followed by the same letter in the column do not differ from each other, Tukey's test, $\mathrm{p}<0.05$ (médias seguidas de mesma letra nas colunas não diferem entre si, teste de Tukey, $\mathrm{p}<0,05)$

${ }^{1}$ Intercrop I= sunn hemp cut at soil level (crotalária cortada rente ao solo); II= sunn hemp pruned at mid-height (crotalária cortada a meia-altura); III= sunn hemp kept with no cuttings (crotalária sem cortes); ${ }^{2} \mathrm{DAMSH}=$ days after the management of the sunn hemp (dias após o corte da crotalária)

Table 2. Height and leaf area of taro in monoculture and intercropped with sunn hemp (altura e área foliar de taro em monocultivo e em consórcio com crotalária). Magé, UFRRJ, 2003.

\begin{tabular}{|c|c|c|c|c|}
\hline \multirow{2}{*}{$\begin{array}{l}\text { Cultivation } \\
\text { system } 1\end{array}$} & \multicolumn{2}{|c|}{ Height (cm) } & \multicolumn{2}{|c|}{ Leaf area $\left(\mathrm{cm}^{2}\right.$ plant $\left.^{-1}\right)$} \\
\hline & 30 DAMSH $^{2}$ & 60 DAMSH $^{2}$ & 30 DAMSH $^{2}$ & 60 DAMSH $^{2}$ \\
\hline Monoculture & $61,7 b^{3}$ & $65,0 \mathrm{~b}$ & $749,4 \mathrm{~b}$ & $785,9 \mathrm{~b}$ \\
\hline Intercrop I1 & 94,2 a & 98,7 a & 927,6 a & 899,8 a \\
\hline Intercrop II & 91,0 a & 97,2 a & 936,7 a & 919,2 a \\
\hline Intercrop III & 96,2 a & $99,2 \mathrm{a}$ & 929,7 a & $920,2 \mathrm{a}$ \\
\hline$\overline{C V}(\%)$ & 7,2 & 8,5 & 5,8 & 7,9 \\
\hline
\end{tabular}

Means followed by the same letter in the column do not differ from each other, Tukey's test, $\mathrm{p}<0.05$ (Médias seguidas de mesma letra nas colunas não diferem entre si, teste de Tukey, $\mathrm{p}<0,05)$.

${ }^{1}$ Intercrop I= sunn hemp cut at soil level (crotalária cortada rente ao solo); II= sunn hemp pruned at mid-height (crotalária cortada a meia-altura); III= sunn hemp kept with no cuttings (crotalária sem cortes); ${ }^{2} \mathrm{DAMSH}=$ days after the management of the sunn hemp (dias após o corte da crotalária).

Table 3. Number and average mass of tillers and yield of tillers and central rhizomes of taro in monoculture and intercropped with sunn hemp (número e massa média de rebentos e produtividade de rebentos e rizomas centrais de taro em monocultivo e em consórcio com crotalária). Magé, UFRRJ, 2003.

\begin{tabular}{lcccc}
\hline \multirow{2}{*}{$\begin{array}{l}\text { Cultivation } \\
\text { system }\end{array}$} & \multirow{2}{*}{$\begin{array}{c}\text { Tillers plant } \\
\text { (no.) }\end{array}$} & Tillers mass (g) & tillers & $\begin{array}{c}\text { central } \\
\text { rhizomes }\end{array}$ \\
\hline Monoculture & $6,4 \mathrm{ab}^{2}$ & $65,2 \mathrm{a}$ & $16,51 \mathrm{a}$ & $12,88 \mathrm{a}$ \\
Intercrop I1 & $6,9 \mathrm{a}$ & $59,2 \mathrm{a}$ & $16,07 \mathrm{a}$ & $12,86 \mathrm{a}$ \\
Intercrop II & $4,7 \mathrm{bc}$ & $63,4 \mathrm{a}$ & $11,90 \mathrm{ab}$ & $12,55 \mathrm{a}$ \\
Intercrop III & $3,2 \mathrm{c}$ & $61,6 \mathrm{a}$ & $7,87 \mathrm{~b}$ & $9,77 \mathrm{a}$ \\
\hline CV (\%) & 16,2 & 12,8 & 23,7 & 22,6 \\
\hline
\end{tabular}

Means followed by the same letter in the column do not differ from each other, Tukey's test, $\mathrm{p}<0.05$ (médias seguidas de mesma letra nas colunas não diferem entre si, teste de Tukey, $\mathrm{p}<0,05)$.

${ }^{1}$ Intercrop I= sunn hemp cut at soil level (crotalária cortada rente ao solo); $\mathrm{II}=$ sunn hemp pruned at mid-height (crotalária cortada a meia-altura); III= sunn hemp kept with no cuttings (crotalária sem cortes); ${ }^{2} \mathrm{DAMSH}=$ days after the management of the sunn hemp (dias após o corte da crotalária). 
Monoculture

$\square$ Sunn hemp cut at soil level

$\square$ Sunn hemp pruned at mid-height

$\square$ Sunn hemp kept with no cuttings

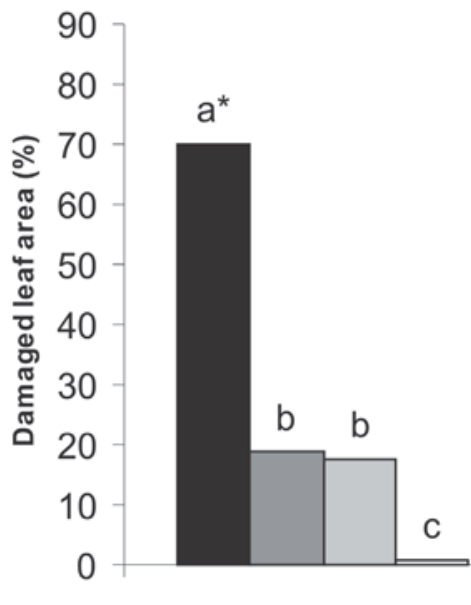

30

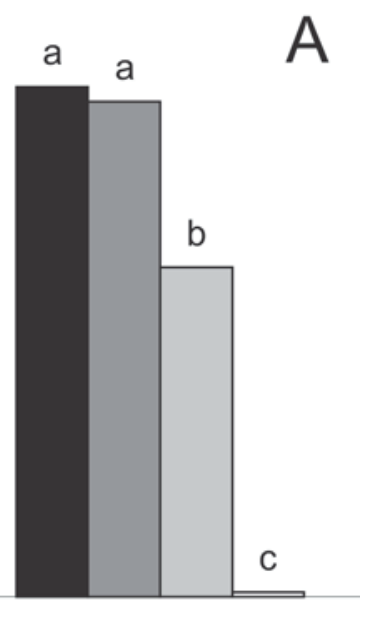

60

Days after the management of the sunn hemp

Monoculture

$\square$ Sunn hemp cut at soil level

$\square$ Sunn hemp pruned at mid-height

$\square$ Sunn hemp kept with no cuttings

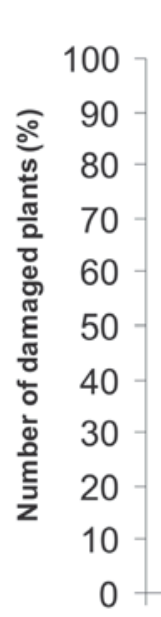

$a^{*}$

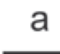

a

B

b

b

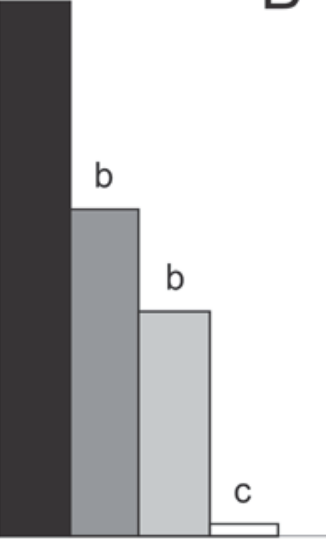

60

30

Days after the management of the sunn hemp

Figure 2. Leaf area (A) and number of plants (B) damaged by leaf burning in taro monoculture and in intercropping with sunn hemp, (Área foliar e número de plantas lesionadas pela queimadas-folhas em monocultivo de taro e em consórcio com crotalária). Magé, UFRRJ, 2003.

Means followed by the same letter in the column do not differ from each other, Tukey's test, $\mathrm{p}<$ 0.05 (Médias seguidas de mesma letra nas colunas não diferem entre si, teste de Tukey, p, 0,05).

the intercropped system did not compromise the yield of taro. Therefore, it was shown that under this study conditions, carried out at a productive pole in Magé, the intercropping with sunn hemp is an alternative for taro cultivation

\section{ACKNOWLEDGMENTS}

Authors thank CAPES for granting a scholarship to Dr. Fábio Luiz de Oliveira.

\section{REFERENCES}

BATAGLIA OC; FURLANI AMC; TEIXEIRA JPF; GALLO JR 1983. Métodos de análise química de plantas. Campinas: Instituto Agronômico de Campinas. IAC. 20 p. (Boletim 78).

BREMNER JM; MULVANEY CS. 1982. Nitrogen total. In: PAGE AL (ed.). Methods of soil analysis. Part 2. $2^{\text {nd }}$ edition. Madison: Soil Science Society of America. p. 595-624.
EMBRAPA - Empresa Brasileira de Pesquisa Agropecuária. Centro Nacional de Pesquisa de Solos. 1997. Manual de métodos de análise de solo. Rio de Janeiro. 212 p.

ESPINDOLA JAA; GUERRA JGM; DE-POLLI H; ALMEIDA DL; ABBOUD ACS. 2005. Adubação verde com leguminosas. Brasília: Embrapa Informação Tecnológica. 49 p.

GLIESSMAN SR. 2005. Agroecologia: processos ecológicos em agricultura sustentável. 2. ed. Porto Alegre: UFRGS. 653 p.

LEIHNER DE; ERNST-SCHAEBEN R; AKONDÉ TP; STEINMULLER N. 1996. Alley cropping on an Ultisol in subhumid Benin. Part II. Changes in crop physiology and tree crop competition. Agroforestry Systems 34: 13-25.

MOREIRA VF. 2003. Produção de biomassa de guandu a partir de diferentes densidades $e$ cultivo de brócolos em faixas intercalares sob manejo orgânico. Seropédica: UFRRJ. 66p. (Tese mestrado).

NOLASCO F. 1984. Estudos para o cultivo inundado de taro (Colocasia esculenta) em monocultivo e em consórcio com Azolla. Viçosa: UFV. 80p. (Tese mestrado).

OLIVEIRA FL. 2004. Alternativas para o manejo orgânico do taro (Colocasia esculenta $L$. Schott) em diferentes condições edafoclimáticas no estado do Rio de Janeiro. Seropédica: UFRRJ. 96p. (Tese doutorado).

OLIVEIRA FL; GUERRA JGM; RIBAS RGT; JUNQUEIRA RM; SILVA EE; ESPINDOLA JAA; ALMEIDA DL; RIBEIRO RLD. 2004. Cultivo orgânico de taro (Colocasia esculenta) entre faixas de guandu na Região Serrana Fluminense. Seropédica: Embrapa Agrobiologia (Comunicado Técnico $\mathrm{n}^{\mathrm{o}}$ 68).

PERIN A. 2001. Desempenho de leguminosas herbáceas perenes com potencial de utilização para cobertura viva e seus efeitos sobre alguns atributos físicos do solo. Seropédica: UFRRJ. 105p. (Tese mestrado).

PIMENTA DS. 1993. Crescimento e produção de taro (Colocasia esculenta), com composto orgânico, amontoa e capina. Viçosa: UFV. 78p. (Tese mestrado).

RIBAS RGT; JUNQUEIRA RM; OLIVEIRA FL; GUERRA JGM; ALMEIDA DL; ALVES BJR; RIBEIRO RLD. 2003. Desempenho do quiabeiro (Abelmoschus esculentus) consorciado com Crotalaria juncea sob manejo orgânico. Agronomia 37: 80-84.

SHEARER GB; KOHL DH. 1986. $\mathrm{N}_{2}$-fixation in field settings: estimations based on natural ${ }^{15} \mathrm{~N}$ abundance. Australian Journal of Plant Physiology 13: 699-756.

TAIZ L; ZEIGER E. 1991. Plant physiology. Redwood City: Benjamin/Cummings Publishing Company. 565 p.

VILPOUX O. 2001. Produção e uso de amido. In: CEREDA MP (ed.) Propriedades gerais do amido. São Paulo: Fundação Cargill. p. 728. (Série Tuberosas Amiláceas Latino Americanas, v. 1) 